Historia Slavorum Occidentis

2020, nr 2 (25)

ISSN 2084-1213

DOI: $10.15804 /$ hso200207

\title{
Kongres Polonoznawstwa Czeskiego 2019/Kongres českých polonistických studií 2019
}

Jesienią 2019 r. odbył się w Republice Czeskiej pierwszy w dziejach, międzynarodowy Kongres Polonoznawstwa Czeskiego. Jego idea narodziła się w 2016 r. podczas „bliźniaczego” Kongresu Czechoznawstwa Polskiego we Wrocławiu, kiedy to przedstawiciele nauki czeskiej zaproponowali, aby zorganizować podobne podsumowanie, tym razem czeskich badań i zainteresowań polonoznawczych. Uchwałę o przygotowaniu tego wydarzenia podjęło Walne Zgromadzenie Polsko-Czeskiego Towarzystwa Naukowego w Cieszynie w maju 2017 r., zapraszając do współpracy ośrodki naukowe z Republiki Czeskiej oraz innych zainteresowanych partnerów. Ostatecznie, w gronie głównych organizatorów znalazło się osiem instytucji naukowych: sześć uniwersytetów czeskich (Uniwersytet Palackiego w Ołomuńcu, Uniwersytet Masaryka w Brnie, Uniwersytet Ostrawski, Uniwersytet Śląski w Opawie, Uniwersytet Hradec Králové, Uniwersytet Karola w Pradze), a także Instytut Historyczny Akademii Nauk Republiki Czeskiej i Polsko-Czeskie Towarzystwo Naukowe. Przedstawiciele tych instytucji weszli w skład Komitetu Organizacyjno-Programowego Kongresu, który zainaugurował swoją działalność na posiedzeniu w Pradze 25 IX 2017 r. W Komitecie zasiadało łącznie 18 osób, pod przewodnictwem prof. Jana Rychlíka z Uniwersytetu Karola w Pradze, doc. Ivany Dobrotovej z Uniwersytetu Palackiego w Ołomuńcu i dr Romana Barona z Instytutu Historii Czeskiej Akademii Nauk. Poza głównymi organizatorami, partnerowało Kongresowi ponad 20 różnych instytucji, urzędów, uczelni i samorządów lokalnych, jak np. Ambasada RP w Pradze, Centrum Pedagogiczne dla Polskiego Szkolnictwa Narodowościowego w Czeskim Cieszynie, Instytut Polski w Pradze, Kraj královéhradecký, Kraj liberecký, Narodowe Muzeum Pedagogiczne i Biblioteka im. J.A. Komeńskiego w Pradze, Stowarzyszenie Solidarność Polsko-Czesko-Słowacka, Uniwersytet w Pardubicach, Konferencja Rektorów Uniwersytetów Śląskich. 
Głównym celem Kongresu było przede wszystkim zbilansowanie stanu czeskich studiów polonoznawczych i próba ustalenia zakresu zainteresowania polską tematyką we wszystkich sferach życia naukowego, społecznego, kulturalnego i politycznego, co w efekcie powinno przybrać postać wielotomowej publikacji. Chodziło także o stworzenie platformy wymiany informacji i doświadczeń, integrację zaineresowanych osób i środowisk, wreszcie - o nawiązanie kontaktów i wzajemną inspirację. Jedną z przesłanek Kongresu stała się bowiem potrzeba ukonstytuowania polonoznawstwa jako interdyscyplinarnej wiedzy o Polsce i o relacjach czesko-polskich w różnych okresach historycznych, zarówno z perspektywy pogranicza, jak i w szerszym kontekście międzynarodowym. Poszerzając ten zakres refleksji, poza dotychczasową polonistykę (rozumianą bardziej w znaczeniu filologicznym), zakładano zdiagnozowanie różnorodnych czynników rozwoju polonoznawstwa i określenie możliwych perspektyw tego rozwoju na przyszłość. Istotne było również zwrócenie uwagi na znaczenie studiów polonoznawczych dla rozwoju stosunków czesko-polskich na poziomie lokalnym, regionalnym, ogólnokrajowym i europejskim. Organizatorzy Kongresu chcieli ponadto pokazać rolę regionów przygranicznych w kształtowaniu stosunków czesko-polskich i znaczenie polskich aspektów w dziedzictwie kulturowym tych regionów.

Kongres miał charakter międzynarodowy, choć z oczywistych względów najwięcej uczestników zapisało się z Republiki Czeskiej i z Polski. Wzięli w nim udział nie tylko przedstawiciele świata akademickiego, ale równie liczna grupa osób z różnych środowisk społecznych i zawodowych powiązanych (lub zainteresowanych) z polonoznawstwem, a także mieszkańcy tych miejscowości, w których Kongres miał swoje kolejne odsłony. Podobnie, jak Kongres we Wrocławiu, Kongres Polonoznawstwa Czeskiego z założenia miał tzw. „sieciowy” charakter, czyli odbywał się w różnych ośrodkach na pograniczu czesko-polskim, od września do listopada 2019 r.

Kongres rozpoczął się konferencją inauguracyjną na Uniwersytecie Palackiego w Ołomuńcu w dniach 10-11 IX 2019 r., połączoną z Walnym Zgromadzeniem Polsko-Czeskiego Towarzystwa Naukowego. W ramach obrad tej konferencji odbyły swoje posiedzenia trzy sekcje naukowe: filologiczno-kulturoznawcza (pod przewodnictwem doc. Ivany Dobrotovej), nauk przyrodniczych (pod przewodnictwem doc. Jaroslava Buriana) oraz sekcja etnologiczna (pod przewodnictwem prof. doc. Mioslava Válki i dr Małgorzaty Michalskiej). Z kolei sesja finalna Kongresu odbyła się w Pradze w dniach 20-22 XI 2019 r., za której organizację odpowiedzialny był Uniwersytet Karola oraz Instytut Historii Czeskiej Akademii Nauk, we współpracy z Ambasadą RP i Instytutem Polskim w Pradze. Poza referatami plenarnymi prof. 
Miloša Řezníka, prof. Lenki Bobkovej oraz prof. Krystyny Kardyni-Pelikanovej, odbyło się wówczas całodniowe posiedzenie sekcji nauk historycznych Kongresu (koordynatorem był dr Roman Baron z Czeskiej Akademii Nauk), a także zostały wygłoszone referaty sprawozdawcze z obrad poszczególnych sekcji tematycznych.

Wszystkich sekcji tematycznych na Kongresie było aż 11. Część z nich, jak wspomniano wyżej, zorganizowała swoje obrady w ramach konferencji inauguracyjnej i sesji finalnej, część natomiast przygotowała odrębne jedno, dwu lub trzydniowe konferencje lub seminaria w różnych ośrodkach Republiki Czeskiej i pogranicza polsko-czeskiego (Praga, Pardubice, Bohumín/Chałupki, Hradec Králové, Opava, Telč). Jeszcze we wrześniu odbyła się bowiem konferencja pt. „Język na pograniczu - granice w języku” zorganizowana przez Uniwersytet Ostrawski, której gestorką była doc. Irena Bogoczová. W październiku z kolei przeprowadzono obrady w trzech miejscach: na Uniwersytecie w Hradec Králové (konferencja „Pogranicze czesko-polskie” - gestorzy prof. Ondřej Felcman i dr Ryszard Gładkiewicz), na Uniwersytecie w Pardubicach (workshop pt. „Idea uniwersytetu trzeciego wieku i uczenia się przez całe życie w czesko-polskim dyskursie" - gestor dr Miroslav Kouba) oraz w Narodowym Muzeum Pedagogicznym i Bibliotece im. J.A. Komeńskiego w Pradze (seminarium sekcji podręcznikowej w dwóch odsłonach: „Bilans-inspiracja-perspektywy. Międzynarodowe seminarium komisji podręcznikowych Europy Środkowej” oraz „Trudne wyzwania dla nauczycieli wczoraj i dziś na przykładzie życia i twórczości Janusza Korczaka i Przemysła Pittra” - gestorki: doc. Blažena Gracová, prof. Danuta Konieczka-Śliwińska, mgr Marta Kmet', mgr Laura Trebel-Gniazdowska, mgr Elżbieta Justyna Baronová). Zaś w listopadzie odbyły się dwie konferencje: na Uniwersytecie w Opawie („Obraz Polski i Polaków w czeskich mediach” - gestor prof. Rudolf Žáček) i na Uniwersytecie Masaryka w Brnie („Czesko-polskie interakcje prawa, ekonomii i językoznawstwa” - gestorzy: prof. Petr Mrkývka, dr Michał Kozieł, dr Roman Madecki).

Niezwykle ciekawym dopełnieniem programu Kongresu stały się liczne wydarzenia towarzyszące, głównie o charakterze kulturalnym, odbywające się w wielu miejscowościach Republiki Czeskiej, jak np. dwie wystawy w Narodowym Muzeum Pedagogicznym i Bibliotece im. J.A. Komeńskiego w Pradze („Historyczne portrety J.A. Komeńskiego i jego współczesnych”, 16 V-21 XI 2019 r. oraz „Historie bezwarunkowego człowieczeństwa - Przemysł Pitter, wyjątkowa postać w XX w." 15-16 X 2019 r.) czy Seminarium Libereckie „Czesko-słowacko-polskie relacje”). W tym zakresie zaangażował się także Instytut Polski w Pradze, organizując we współpracy z miejscowymi partnerami przegląd polskich filmów (w Ołomuńcu, 
Hradec Králové, Ostrawie, Opawie, Brnie i Pardubicach) oraz cykl wystaw poświęconych problematyce polskiej (np. wystawa „Plakaty programowe Instytutu Polskiego” w Ołomuńcu, wystawa „Niepodległy” w Pardubicach i Opawie, wystawa "Józef Piłsudski” w Brnie/Telču czy wystawa „Architektura dla kultury” w Libercu).

Jeszcze w czasie trwania Kongresu pojawiały się zapytania uczestników, czy wydarzenie to będzie miało swoją kontynuację, a jeśli tak, to kiedy. Naprzeciw tego rodzaju sugestiom wychodziło zapewnienie organizatorów, że zarówno szeroki zakres imprez odbywających się w ramach Kongresu, jak i duża liczba uczestników, pozwalają planować w przyszłości przygotowanie podobnego spotkania. Ostateczną decyzję w tej kwestii podjęto na wspólnym posiedzeniu Komitetu Organizacyjno-Programowego Kongresów Czechoznawstwa Polskiego, Komitetu Organizacyjno-Programowego Kongresu Poloznawstwa Czeskiego i zarządu Polsko-Czeskiego Towarzystwa Naukowego, które odbyło się we Wrocławiu 13 XII 2019 r. Postanowiono wówczas o integracji obu Kongresów i organizacji w przyszłości jednego, wspólnego przedsięwzięcia, naprzemiennie (raz w Polsce, raz w Republice Czeskiej), w odstępach 3-5-letnich. Pierwszy tego typu polsko-czeski Kongres zaplanowano wstępnie na jesień $2022 \mathrm{r}$. lub wiosnę $2023 \mathrm{r}$.

Dr hab. Danuta Konieczka-Śliwińska, prof. UAM

Wydział Historii

Uniwersytet im. Adama Mickiewicza w Poznaniu

ul. Uniwersytetu Poznańskiego 7

61-614 Poznań

e-mail: konsliw@amu.edu.pl

ORCID: 0000-0001-6943-9167 